\title{
The Impact of Intellectual Capital on Firm Performance of the Turkish Real Estate Companies Before and After the Crisis
}

\author{
Sedeaq Nassar, (PhD) \\ Marmara University, Bahçelievler, Istanbul, Turkey
}

Doi: 10.19044/esj.2018.v14n1p29 URL:http://dx.doi.org/10.19044/esj.2018.v14n1p29

\begin{abstract}
Purpose- The main purpose of this study is to find the impact of intellectual capital on firm performance of real estate companies listed in Borsa Istanbul, using data of 27 listed companies over the period 2004-2015. Value Added Intellectual Coefficient (VAIC) method is utilized as a measure of intellectual capital (IC).

Methodology- An OLS regression is used to examine the impact of intellectual capital (VAIC); Human capital efficiency (HCE), Structural capital efficiency (SCE), and Capital employed efficiency (CEE) on market, productivity, and financial performance.

Findings- The findings show that SCE consider as a key role of value creation in real estate companies where has a positive significant relation with $\mathrm{MB}$, ROE, and EPS before the crisis and with ROA and ROE after the crisis. HCE show a positive significant relation with ROA and ROE before the crisis and a negative significant association with MB and ATO after the crisis. CEE show a negative significant impact on ATO after the crisis. VAIC shows a significant positive impact on ROA, ROE, and EPS before the crisis, while it has the same relation with ROE after the crisis.

Conclusion- Although the good result of using intellectual capital for value creation, real estate Turkish companies still weakly depend on its intellectual capital.
\end{abstract}

Keywords: Intellectual capital, Human capital, Structural capital, Capital employed, Value added intellectual coefficient

\section{Introduction}

Intellectual capital plays a significant role for value creation in today's economies and organizations, where organizations in knowledge-based economies have been depending on knowledge assets rather than tangible assets to enhance its competitive advantages (Hamzah \& Ismail, 2008). 
According to the OECD (2008), several organizations enhance employee skills through training, research, and development. They also invest in customer and supplier relations, technology, and information systems. Such actions, which are often called as intellectual capital investments, are increasing day by day on the expense of physical and financial capital investments. Such shift in investment behavior is attributable to the increasing attention to knowledge-based economies (Stewart, 2002; Zeghal \& Maaloul, 2010).

While knowledge can be described as information, alongside with the realization of how to use it (Mayo, 2001); Mårtensson (2000) defines knowledge management as the company's capability to manage and control the intellectual capital. Intellectual capital (IC) can be defined as the knowledge that can be converted into profit by exploiting the non-financial and nonphysical resources of the company (Sullivan, 1999). It should be noted that there are many definitions available for intellectual capital. Several researchers have defined intellectual capital from a knowledge-based economy view and how intellectual capital contributes in maximizing value creation efficiency. The economic developments have led to significant changes in company's' operations on the global markets. Nowadays, we are seeing an increasing focus to investment in intellectual resources, which enhances the competitive advantage of a company. This fact may cause the need to find a new way to manage and measure companies' performance through their intangible sources (Jurczak, 2008).

Several concepts like intellectual capital, intellectual assets, knowledge assets, and intangible assets can be used interchangeably (Bontis et al., 2000; Kujansivu \& Lönnqvist, 2007; Lev, 2001; Roos et al., 1997). Peppard \& Rylander (2001) argued that the combination of intellectual assets plays a key role in creating value for the company. Similarly, Mavridis \& Kyrmizoglou (2005) pointed out the possible effects of intangible assets on value creation. Moreover, Edvinsson \& Malone (1997) said that the knowledge, information, and experience are the most important factors in value creation.

The financial sector is one of the most suitable areas for studying and researching IC because of the service and intellectual nature of the financial industry, which focuses on knowledge and employee skills, more than financial and physical capital. In addition, this sector is known for its availability of reliable data (Mavridis, 2004). It is also believed that using IC in creating value in knowledge-based sectors, such as financial sector, is higher than other economic sectors (El-Bannany, 2008). The Turkish financial sector is considered as one of the most biggest sectors in Turkey and has a crucial role in economic development (Calisir et al., 2010). 
The main objective of this study is to examine the relationship between intellectual capital and firm performance of real estate companies listed in Borsa Istanbul before and after the crisis. The broad area of study, under which the paper falls in, is the area of market, productivity, and financial performance within the Intellectual Capital context.

\section{Intellectual Capital Definition}

Jon Kenneth Galbraith was the one, who introduced the intellectual capital in 1969 (Khalique, Shaari, Abdul, \& Isa, 2011). Although an extended period of time has elapsed since its introduction, no consensus exists about its definition. However, the existing definitions are not considerably different from each other (Tayles et al., 2007). The vast majority of the definitions are essentially based on similar concepts like information, knowledge, experiences and skills of employees, customer and employees' loyalty and satisfaction, firm reputation, organizational systems and procedures, organizational cultures, and value creation (Barathi Kamath, 2007; Brooking, 1996; Edvinsson \& Malone, 1997; Roos \& Roos, 1997; Sullivan, 1999; Yalama \& Coskun, 2007), among others.

According to Edvinsson (1997); Kamath (2007); Pulic ( 2000); Roos et al. (1997); Stewart (1997); Sullivan (1999); Zeghal \& Maaloul (2010) IC is the company's intellectual ability, which presents how efficiently they use physical capital and intellectual potential to create value or how efficiently knowledge transformed into value. Moreover, Bontis et al. (2000); Brooking (1996); Roos \& Roos (1997); Sveiby (1997); Yalama \& Coskun (2007) stated that IC is the hidden resources which are not reported in financial statements, which also can be used as a competitive advantage and to maximize the future value of the company. In general, most definitions focus on how companies use knowledge (intangible sources) effectively to enhance a company's competitive advantage (or maximize the value of the firm).

\section{IC components}

Value Added Intellectual Coefficient (VAIC ${ }^{\mathrm{TM}}$ ) method which created and developed by Pulic (1998, 2000, and 2002), is considered as an instrument used by several researchers to measure IC performance (Al-Shubiri, 2013; Chen Goh, 2005; Chen et al., 2005; Deris et al., 2013; Djamil et al., 2013; Ho \& Williams, 2003; Joshi et al., 2010; Kamath, 2007; Kujansivu \& Lönnqvist, 2007; Latif et al., 2012; Pew Tan et al., 2007; Wang, 2011; Yalama \& Coskun, 2007). VAIC method is suggested as one of the most appropriate measurements of IC performance at the level of private and public organizations (Joshi et al., 2010; Kamath, 2007; Zeghal \& Maaloul, 2010). A review of the literature showed a lack in using VAIC method for measuring IC and its impact on firm performance. Despite the limited of the use of VAIC 
approach in real estate sector, there are several researches conducted this method in many sectors; Banking, Industrial, Financial, IT and communication, and other sectors (Amin et al., 2014; Bin Ahmad \& Mushraf, 2011; Bontis, Bontis et al., 2000; Dženopoljac et al., 2016; Huihui \& Jitian, 2010; Kamath, 2008; Kendirli et al., 2014; Li \& Wu, 2004; Matinfard \& Khavari, 2015; Mehralian et al., 2012; Mehri et al., 2013; Molodchik \& Bykova, 2011; Phusavat et al., 2011; Radianto, 2011; Zeglat \& Zigan, 2013). The VAIC method is very significant because it allows us to examine the contribution of both intellectual resources (human and structural) as well as tangible (physical and financial) resources in creates the VA of the firm.

Pulic's approach is composed of three aspects of intellectual capital as Human Capital Efficiency (HCE), Structural Capital Efficiency (SCE), and Capital Employed Efficiency (CEE). Human Capital (HC) is considered as the most significant factor of innovation and competitiveness (Bozbura, 2004). According to Pulic (1998), HC is not only a collection of employees' characteristics, capabilities, skills, etc., but also, the value of invested capital in employees' knowledge (training, R\&D, wages, salaries, etc.) intellectual abilities, experiences, competencies of individual workers, which are not reflected in the financial statements.

Structural capital (SC) defined as the organization's potential and capabilities in facing the internal and external challenges (Cabrita \& Vaz, 2005). Structural capital is the intellectual asset which is independent of individuals; hence, structural capital remains after employees leave the company (Chen et al., 2005; Sydler et al., 2014). Therefore, SC is considered as a non-human stock of knowledge, that includes each of the information technology, trademarks, patents, and plans, which can be represented by databases, software, hardware, and organizational structures (Al-Zoubi, 2013; Chen et. al., 2005; Moradi et al., 2013). Capital Employed (CE) is the tangible assets part of capital and contain both physical and financial assets. The physical part represent fixed assets and raw materials, while the financial part include other existing assets after employees leave the company (Basso et al., 2010). According to Pulic (2004), CE refers to physical and financial capital like book value of net assets. Similarly, Chen et. al., (2005); Mosavi et. al., (2012); Rehman et. al., (2014); Rehman et. al., (2012) are calculated CE as the sum of physical and financial assets, or by deducting intangible assets from total assets.

\section{Literature review}

The first empirical study of intellectual capital has been conducted by Pulic (1998), which examine the effect of IC on firm performance. Pulic (1998) created a new method using accounting tools to measure IC and companies' financial performance. It has opened the way widely for 
researchers from many countries to measure IC efficiency for banking and other sectors (Abdulsalam et al., 2011). Bontis, (1998a) shed some light on the development of some terms and measurement models relating to IC and its effect on firm performance.. Luthy (1998) presented an operational definition of IC and a framework for classifying and identifying the various elements of intellectual capital. Moreover, the paper explored several methods measuring IC and its components, as well as, measurements of organizational levels.

Bontis et. al., (2000) studied the effects accounting IC components (HC, SC and relational capital) on performance of Malaysian service and nonservice companies. They revealed that $\mathrm{HC}$ and relational capital have positive impact on the service sector. Another study conducted in Malaysia by Muhammad \& Ismail (2014) examined the effect of IC efficiency on performance of financial sectors. The results pointed out that the banking sector is depending on intellectual capital more than the brokerage sector and the insurance sector. Moreover, the findings showed significant positive relation between IC and ROA. The study also pointed out that the Malaysian financial sector relies on financial and physical capital more than intellectual capital in creating market value. Goh (2005) documented similar results, where Malaysian banks have good financial performance, thus have low intellectual financial coefficients.

El-Bannany (2012) analyzed the effects of the recent economic crisis on IC in UAE banking sector. Using multiple regression analysis over 20042010. The findings showed significant effect of the recent economic crisis and the market structure on IC. In addition, the findings indicated that the independent variables (IT investments, size, and barriers to entry, profitability, risk, age, and listing age) are important and positively affect IC performance. These results are fully compatible with the findings of El-Bannany, (2008), which was conducted in the UK banking sector over the period 1999-2005.

Shih et. al., (2010) examined correlation between knowledge creation and intellectual capital in Taiwan's banking sector. The results showed a positive impact of knowledge creation on $\mathrm{HC}, \mathrm{SC}$ and customer capital. In addition, HC performance showed significant effect on customer capital and SC. Moreover, customer capital positively influence structural capital and banks with high human capital has good operational efficiency.

Mondal \& Ghosh (2012) explored the relation between IC and performance in terms of ROA, ROE and ATO for 65 Indian banks for 19992008. The findings highlighted significant relation between IC and firm profitability (ROA and ROE) and productivity performance (ATO). They also added that human capital has a major effect on banks performance. These findings are parallel with Kamath, (2007) that indicate that foreign banks show perfect use of $\mathrm{HC}$ to create value, whereas public banks rely on $\mathrm{CE}$ to achieve good performance. 
Mention \& Bontis (2013) analyzed the relation between IC and its components with banks performance in Luxembourg and Belgium. The findings show that human capital affects banks performance directly and indirectly, whereas structural capital and relational capital both presented insignificant positive effect on banks performance.

Mavridis \& Kyrmizoglou (2005) discussed the effect of IC components on Greek banks performance. Seventeen biggest banks have been analyzed over the period 1996-1999 using a predictive (regression) analysis. The findings presented significant positive relation between value added and human capital and physical capital. Similarly, significant positive correlation has existed between value added and gross profit, net profit.

Joshi et al., (2010) explored the relation between IC (HC, SC, and CE) and banks' performance over the period 2005-2007 using the VAICTM model. Significant relation between $\mathrm{HC}$ and value creation efficiency has been reported, where human capital efficiency is relatively higher than structural capital efficiency and capital employed efficiency. Moreover, bank size, number of employees, and shareholder equity has no influence on IC performance of Australian banks

Cabrita \& Vaz, (2005) studied the same topic for the Portuguese banking sector. The results indicated a significant and positive relation between IC and banks performance. In addition, the study found that value creation exists when the IC elements interact, which means that more the interaction among IC elements, the more value is created. This results are completely compatible with the findings of a study conducted by Cabrita \& Bontis (2008), who showed that human capital is an important part of IC that helps banks understand how can employees create value.

Holienka \& Pilková (2014) explored the impact of IC and its elements on firm performance before and after the crisis on SMEs in 10 different sectors in Slovakia by using the VAICTM model. Panel data consisting of 2008 (precrisis year), 2011 for (post-crisis year) was utilized to analyze and compare the differences in the impact of IC on SMEs performance (ROA). By using a regression model, the results showed an increasing role of IC in predicting firm's financial performance in the post-crisis period compared to the precrisis period. Furthermore, the results indicated that IC in generally has a significant impact on firm performance, while its components (HC, SC, and CE) showed a different result. Similarly, Radianto (2011) results show that IC is positively affects bank performance (ROA) over pre and post-crisis periods. The study of Sumedrea (2013) is also partly compatible with Holienka \& Pilková (2014) and Radianto (2011), where the findings indicated that in the crisis period HC and SC play a major role in companies development, while financial capital is the important factor that affect firm profitability. 
Narwal \& Yadav (2017) examined the impact of IC on profitability and productivity of the Indian real estate sector. Pearson correlation and OLS regression analysis consisting of 2005 to 2015 were utilized to find the impact of IC and its components on real estate companies' profitability and productivity. The findings indicated that IC has a significant positive impact only on profitability of the Indian real estate sector.

Pitelli Britto et al., (2014) investigated the relationship between IC and its components (HCE, SCE, and CEE) with traditional accounting measures of efficiency (ROIC and profit margins). The correlation and OLS regression analysis were used to examine this relation over the period of 2007 to 2011 for the Brazilian real estate companies. The findings showed that IC has a significant negative association with market value. In addition, the results showed that CEE is the key component in explaining the value creation of real estate companies.

Huihui \& Jitian (2010) studied the impact of IC on financial performance of 80 real estate companies listed in the Shanghai and Shenzhen stock Exchange of China. The VAIC is used to measure the IC and 12 traditional accounting ratios are used to measure the firm financial performance. The findings of correlation and OLS analysis showed that there is a significant positive impact of IC and its component HCE on financial performance where $\mathrm{HCE}$ is the key role in promoting the financial performance of real estate companies.

In Turkey, Ozkan et. al., (2016) studied intellectual capital and bank financial performance (ROA) relation over the period 2005 and 2014 using VAIC model. The findings indicated that $\mathrm{HC}$ and $\mathrm{CE}$ both have positive influence on financial performance of banks (ROA). However, CE is affects banks financial performance more than HC. Yalama \& Coskun (2007) reached similar results to some extent, where they found a positive impact of IC on banks profitability (ROA and ROE) in Turkish banks listed on Istanbul stock exchange (ISE) over the period 1995-2004. Calisir et al. (2011) studied the trend of intellectual capital performance in both development and investment banks in Turkey over the period 2003-2007. The results showed a decreasing trend of VAIC efficiency started in 2003, which then began to increase in 2005 and 2006.

\section{Data and methodology}

The main purpose of this study is to investigate the impact of intellectual capital on market, productivity and financial performance of the real estate companies listed on Borsa Istanbul before and after the financial crisis. This study is conducted on the real estate companies listed on Borsa Istanbul, with a total of 27 companies. Since the objective of this study is to measure the impact of IC on the firm performance pre-and post-financial 
crisis, the study divides research period into two parts, first part refers to the pre-crisis period over 2004-2007, and second part refers to the post-crisis period over 2010-2015. Data is collected from several sources (i) the main source is Finnet Analysis Expert database (ii) companys' annual reports of 2004 to 2015, which are available and collected from companies' websites, in addition to Borsa Istanbul website. Companies that are lacking or missing relevant information are excluded from the sample.

Value added intellectual coefficient "VAIC" method was utilized to measure the impact of IC and its components (HCE, SCE, and CEE), where to measure firm performance a set on indicators related to market performance (PE and $\mathrm{MB}$ ), productivity performance (ATO) and financial performance (ROE, ROA and EPS) was utilized.

The study uses the ordinary regression model (OLS) to find and to compare the impact of IC (independent variables) on firm performance (dependent variables) between two periods; before the crisis period (20042007) and after the crisis period (2010-2015). The variables of the study are selected by following the literature. The variables used in the study presented in Table 1.

Table 1 Summary of all variables used in the study.

\begin{tabular}{|c|c|c|}
\hline Variables & Abbreviation & Equation \\
\hline \multicolumn{3}{|c|}{ Independent Variables } \\
\hline Human Capital Efficiency & $\mathrm{HCE}$ & VA/HC \\
\hline $\begin{array}{l}\text { Structural Capital } \\
\text { Efficiency }\end{array}$ & SCE & SC/VA \\
\hline $\begin{array}{c}\text { Capital Employed } \\
\text { Efficiency }\end{array}$ & CEE & $\begin{array}{l}\text { VA/CE (total assets minus intangible } \\
\text { assets) }\end{array}$ \\
\hline $\begin{array}{c}\text { Value Added Intellectual } \\
\text { Coefficient } \\
\end{array}$ & VAIC & $\mathrm{HCE}+\mathrm{SCE}+\mathrm{CEE}$ \\
\hline \multicolumn{3}{|c|}{ Dependent Variables } \\
\hline Market to Book value & $\mathrm{MB}$ & Market Capitalization/Book Value \\
\hline Price-Earnings ratio & $\mathrm{PE}$ & Market value per share/Earning per share \\
\hline Assets Turn Over & ATO & Total Revenue/Total Book Value \\
\hline Return on Assets & ROA & Net Income/Total Assets \\
\hline Return on Equity & ROE & Net Income/Total Equity \\
\hline Earnings per Share & EPS & $\begin{array}{c}\text { (Net Income-Preferred Dividends)/ } \\
\text { (Average Outstanding Shares) }\end{array}$ \\
\hline \multicolumn{3}{|c|}{ Control Variables } \\
\hline Firm Age & FAGE & $\begin{array}{c}\text { Age of the company from its } \\
\text { establishment time }\end{array}$ \\
\hline Firm Size & FSIZE & Log of firm's total assets \\
\hline Firm Leverage & FLEV & Total debt / Book value of total assets \\
\hline
\end{tabular}

\section{Study hypotheses}

There are three main research hypotheses derived from the study objectives. These hypotheses are listed as follow: 
H1: There is a significant positive relationship between Value Added Intellectual Capital (VAIC) and its components (HCE, SCE and CEE) and firms' market performance (MB, PE).

$\mathrm{H} 2$ : There is a significant positive relationship between Value Added Intellectual Capital (VAIC) and its components (HCE, SCE and CEE) and firms' productivity (ATO).

H3: There is a significant positive relationship between Value Added Intellectual Capital (VAIC) and its components (HCE, SCE and CEE) and firms' financial performance (ROA, ROE, EPS).

\section{Descriptive Statistics}

Descriptive statistics of independent, dependent and control variables of 27 sample companies are presented in table 2 shows the descriptive of the study variables for the pre-and post-crisis period.

Table 2 Descriptive statistics

\begin{tabular}{|c|c|c|c|c|c|c|c|c|c|c|c|c|c|}
\hline & \multirow{2}{*}{ 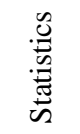 } & \multicolumn{3}{|c|}{$\begin{array}{c}\text { Independent } \\
\text { Variables }\end{array}$} & \multicolumn{6}{|c|}{ Dependent Variables } & \multicolumn{3}{|c|}{ Control variables } \\
\hline & & $\mathrm{HCE}$ & SCE & CEE & MB & PE & ATO & ROA & ROE & EPS & FAGE & FSIZE & FLEV \\
\hline \multirow{3}{*}{$\begin{array}{l}\text { Before } \\
\text { crisis }\end{array}$} & $\mathrm{N}$ & 108 & 108 & 108 & 108 & 108 & 108 & 108 & 108 & 108 & 108 & 108 & 108 \\
\hline & Mean & 7.50 & 0.64 & 0.59 & 1.07 & 5.50 & 1.42 & -0.01 & 3.61 & 0.14 & 8.29 & 16.79 & 0.38 \\
\hline & SD & 10.36 & 0.41 & 1.64 & 0.89 & 10.35 & 7.30 & 0.45 & 11.67 & 1.08 & 7.88 & 2.42 & 0.81 \\
\hline \multirow{3}{*}{$\begin{array}{l}\text { After } \\
\text { crisis }\end{array}$} & $\mathrm{N}$ & 162 & 162 & 162 & 162 & 162 & 162 & 162 & 162 & 162 & 162 & 162 & 162 \\
\hline & Mean & 12.67 & 0.82 & $\begin{array}{c}- \\
0.18 \\
\end{array}$ & 0.99 & 8.41 & 0.30 & 0.07 & 9.07 & 0.61 & 14.72 & 17.56 & 1.47 \\
\hline & SD & 10.38 & 0.22 & 0.88 & 1.36 & 9.98 & 0.99 & 0.11 & 14.03 & 1.50 & 8.64 & 1.64 & 5.34 \\
\hline
\end{tabular}

HCE is human capital efficiency, SCE is structural capital efficiency, CEE is capital employed efficiency, MB is market to book ratio, $\mathrm{PE}$ is price-earnings ratio, ATO is assets turnover, ROA is return on assets, ROE is return on equity, EPS is earnings per share, FAGE is firm age, FSIZE is firm size, FLEV is firm leverage.

Table 2 shows that the three components of VAIC (HCE, SCE, and $\mathrm{CEE})$ have a respective mean value of $(7.5,0.64$, and -0.59$)$ before the crisis and a respective mean value of $(12.67,0.82$, and -0.18$)$ after crisis for the real estate companies. According to this result, one can say that $\mathrm{HC}$ is the most effective component in the issue of value creation than SC and $\mathrm{CE}$ for the study period. The market performance variable (PE) do not show any specific trend before and after crisis, where it is quite fluctuating on the average. Whereas, the (MB) indicates performance range to 89\%. Likewise, the productivity ratio (ATO) does not appear any specific trend before the crisis, where shows a good range to $99 \%$ after the crisis. Financial performance ratios (ROA, ROE, and EPS) only ROA ratio shows a good average ranging at (0.45 and 0.11 ) before and after the crisis respectively. The standard deviation for the independent variables is the highest in HCE and for dependent variables is the highest in ROE before and after the crisis. From above explanation, one 
can say that there are no significant differences in descriptive between the study's variables before and after the crisis.

\section{Regression analysis}

Table 3 presents the OLS regression statistics among each of dependent, control, and independent variables before and after the crisis. Model 1 presents the regression statistics between dependent variables and the components of VAIC through control variable. Model 2 depicts the regression statistics between dependent variables and VAIC through control variables.

The results of table 3 shows that VAIC has no impact on firms' market performance (MB, PE), while its component $\mathrm{HCE}$ has a significant negative impact on $\mathrm{MB}$ after the crisis. SCE has a significant positive impact on MB before the crisis, and CEE has a significant negative impact on PE after the crisis. In addition, productivity performance variable (ATO) has no relationship with VAIC and its components before the crisis, while after the crisis, it has a significant negative relation with $\mathrm{HCE}$ and $\mathrm{CEE}$.

Moreover, regarding firms' financial performance, the results of table 3 show that VAIC has a significant positive impact on ROA, ROE, and EPS before the crisis and has the same relation with ROE after the crisis. HCE has a significant positive impact on ROA and ROE only before the crisis. SCE has a significant positive impact on ROE and EPS before the crisis and the same relation with ROA and ROE after the crisis. CEE has no relation with any of financial performance variables.

Table 3 Regression analysis

\begin{tabular}{|c|c|c|c|c|c|c|c|c|c|c|c|c|}
\hline \multicolumn{13}{|c|}{ Before Crisis 2004 - 2007} \\
\hline \multirow[b]{2}{*}{$\begin{array}{c}\text { Vari } \\
\text { able } \\
\text { s }\end{array}$} & \multicolumn{2}{|c|}{ MB } & \multicolumn{2}{|c|}{$\mathrm{PE}$} & \multicolumn{2}{|c|}{ ATO } & \multicolumn{2}{|c|}{ ROA } & \multicolumn{2}{|c|}{$\mathrm{ROE}$} & \multicolumn{2}{|c|}{ EPS } \\
\hline & $\begin{array}{c}\text { Mod } \\
\text { el1 }\end{array}$ & $\begin{array}{l}\text { Mod } \\
\text { el2 }\end{array}$ & $\begin{array}{c}\text { Mod } \\
\text { el1 }\end{array}$ & $\begin{array}{c}\text { Mo } \\
\text { del } \\
2 \\
\end{array}$ & $\begin{array}{l}\text { Mod } \\
\text { el1 }\end{array}$ & $\begin{array}{c}\text { Mo } \\
\text { del } \\
2\end{array}$ & $\begin{array}{l}\text { Mod } \\
\text { el1 }\end{array}$ & $\begin{array}{l}\text { Mo } \\
\text { del2 }\end{array}$ & $\begin{array}{c}\text { Mo } \\
\text { del } \\
1\end{array}$ & $\begin{array}{c}\text { Mod } \\
\text { el2 }\end{array}$ & $\begin{array}{c}\text { Mode } \\
11\end{array}$ & $\begin{array}{c}\text { Mod } \\
\text { el2 }\end{array}$ \\
\hline $\begin{array}{l}\text { Con } \\
\text { stant }\end{array}$ & $\begin{array}{c}- \\
0.62 \\
3\end{array}$ & $\begin{array}{c}- \\
1.11 \\
4\end{array}$ & $\begin{array}{l}28.39 \\
4 * * *\end{array}$ & $\begin{array}{c}25 . \\
295\end{array}$ & $\begin{array}{c}- \\
16.5 \\
56\end{array}$ & $\begin{array}{c}- \\
8.4 \\
55\end{array}$ & $\begin{array}{c}- \\
0.12 \\
7\end{array}$ & $\begin{array}{c}- \\
0.1 \\
80\end{array}$ & $\begin{array}{c}- \\
17 . \\
649\end{array}$ & $\begin{array}{c}- \\
23.0 \\
36\end{array}$ & $\begin{array}{c}- \\
0.928\end{array}$ & $\begin{array}{c}- \\
2.18 \\
2\end{array}$ \\
\hline \multicolumn{13}{|c|}{ Control variables } \\
\hline $\begin{array}{c}\text { FAG } \\
\text { E }\end{array}$ & $\begin{array}{c}0.04 \\
4\end{array}$ & $\begin{array}{c}0.06 \\
6\end{array}$ & $\begin{array}{c}- \\
0.255 \\
* * *\end{array}$ & $\begin{array}{c}- \\
0.2 \\
40\end{array}$ & $\begin{array}{c}0.00 \\
4\end{array}$ & $\begin{array}{c}- \\
0.0 \\
29\end{array}$ & $\begin{array}{c}0.10 \\
0\end{array}$ & $\begin{array}{l}0.1 \\
25\end{array}$ & $\begin{array}{c}0.2 \\
50\end{array}$ & $\begin{array}{c}0.30 \\
5^{*}\end{array}$ & 0.147 & $\begin{array}{l}0.20 \\
8 * * *\end{array}$ \\
\hline $\begin{array}{l}\text { FSI } \\
\text { ZE }\end{array}$ & $\begin{array}{c}0.27 \\
2 * * \\
*\end{array}$ & $\begin{array}{l}0.35 \\
1 * * *\end{array}$ & 0.134 & $\begin{array}{c}- \\
0.1 \\
51\end{array}$ & $\begin{array}{l}0.27 \\
3 * * *\end{array}$ & $\begin{array}{c}0.1 \\
19\end{array}$ & $\begin{array}{c}0.16 \\
6\end{array}$ & $\begin{array}{c}0.0 \\
42\end{array}$ & $\begin{array}{c}0.2 \\
10\end{array}$ & $\begin{array}{c}0.08 \\
8\end{array}$ & 0.137 & $\begin{array}{c}0.14 \\
2\end{array}$ \\
\hline $\begin{array}{c}\text { FLE } \\
\mathrm{V}\end{array}$ & $\begin{array}{c}- \\
0.31 \\
5 * *\end{array}$ & $\begin{array}{c}- \\
0.33 \\
8 * *\end{array}$ & $\begin{array}{c}- \\
0.115\end{array}$ & $\begin{array}{c}- \\
0.0 \\
16\end{array}$ & $\begin{array}{c}- \\
0.16 \\
6\end{array}$ & $\begin{array}{c}- \\
0.0 \\
37 \\
\end{array}$ & $\begin{array}{c}- \\
0.22 \\
4\end{array}$ & $\begin{array}{c}- \\
0.0 \\
48\end{array}$ & $\begin{array}{c}- \\
0.3 \\
67 *\end{array}$ & $\begin{array}{c}- \\
0.08 \\
0\end{array}$ & $\begin{array}{c}- \\
0.523 \\
*\end{array}$ & $\begin{array}{c}- \\
0.34 \\
4 *\end{array}$ \\
\hline \multicolumn{13}{|c|}{ Independent variables } \\
\hline $\mathrm{HCE}$ & $\begin{array}{c}- \\
0.10 \\
9\end{array}$ & & $\begin{array}{c}- \\
0.155\end{array}$ & & $\begin{array}{c}- \\
0.11 \\
3\end{array}$ & & $\begin{array}{l}0.37 \\
5 * *\end{array}$ & & $\begin{array}{c}0.2 \\
49 *\end{array}$ & & 0.000 & \\
\hline
\end{tabular}




\begin{tabular}{|c|c|c|c|c|c|c|c|c|c|c|c|c|}
\hline SCE & $\begin{array}{c}0.06 \\
9 * * \\
*\end{array}$ & & 0.283 & & $\begin{array}{c}0.19 \\
0\end{array}$ & & $\begin{array}{c}0.16 \\
3\end{array}$ & & $\begin{array}{c}0.4 \\
87 *\end{array}$ & & $\begin{array}{c}0.449 \\
*\end{array}$ & \\
\hline CEE & $\begin{array}{c}0.11 \\
2\end{array}$ & & $\begin{array}{c}- \\
0.034\end{array}$ & & $\begin{array}{c}0.28 \\
8\end{array}$ & & $\begin{array}{c}0.02 \\
3\end{array}$ & & $\begin{array}{l}0.0 \\
02\end{array}$ & & 0.110 & \\
\hline $\begin{array}{c}\text { VAI } \\
\text { C }\end{array}$ & & $\begin{array}{c}0.07 \\
7\end{array}$ & & $\begin{array}{c}0.0 \\
66\end{array}$ & & $\begin{array}{l}0.2 \\
10\end{array}$ & & $\begin{array}{c}0.3 \\
71^{*}\end{array}$ & & $\begin{array}{c}0.42 \\
9 *\end{array}$ & & $\begin{array}{l}0.23 \\
2 * * *\end{array}$ \\
\hline $\begin{array}{c}\text { F- } \\
\text { Stat. }\end{array}$ & 1.89 & 1.16 & 0.99 & $\begin{array}{c}0.9 \\
4\end{array}$ & 1.27 & $\begin{array}{c}1.4 \\
5\end{array}$ & 1.29 & $\begin{array}{c}3.1 \\
7\end{array}$ & $\begin{array}{c}3.4 \\
8\end{array}$ & $\begin{array}{c}10.2 \\
7\end{array}$ & 5.56 & 6.92 \\
\hline $\begin{array}{l}\text { Prob } \\
\text { (F) }\end{array}$ & $\begin{array}{c}0.12 \\
5\end{array}$ & $\begin{array}{c}0.34 \\
1 \\
\end{array}$ & 0.419 & $\begin{array}{c}0.4 \\
86 \\
\end{array}$ & $\begin{array}{c}0.29 \\
2 \\
\end{array}$ & $\begin{array}{l}0.2 \\
05 \\
\end{array}$ & $\begin{array}{c}0.28 \\
4\end{array}$ & $\begin{array}{l}0.0 \\
07 \\
\end{array}$ & $\begin{array}{l}0.0 \\
13\end{array}$ & $\begin{array}{c}0.00 \\
0\end{array}$ & 0.001 & $\begin{array}{c}0.00 \\
0\end{array}$ \\
\hline $\begin{array}{l}\text { R- } \\
\text { squa } \\
\text { re }\end{array}$ & $\begin{array}{c}0.11 \\
7\end{array}$ & $\begin{array}{c}0.13 \\
1\end{array}$ & 0.065 & $\begin{array}{c}0.1 \\
08\end{array}$ & $\begin{array}{c}0.08 \\
2\end{array}$ & $\begin{array}{c}0.1 \\
58\end{array}$ & $\begin{array}{c}0.08 \\
3\end{array}$ & $\begin{array}{l}0.2 \\
91\end{array}$ & $\begin{array}{c}0.1 \\
96\end{array}$ & $\begin{array}{c}0.57 \\
1\end{array}$ & 0.281 & $\begin{array}{c}0.47 \\
3\end{array}$ \\
\hline $\begin{array}{l}\text { R- } \\
\text { Squa } \\
\text { re } \\
\text { Cha } \\
\text { nge }\end{array}$ & & $\begin{array}{c}0.01 \\
4\end{array}$ & & $\begin{array}{l}0.0 \\
43\end{array}$ & & $\begin{array}{l}0.0 \\
76\end{array}$ & & $\begin{array}{l}0.2 \\
08\end{array}$ & & $\begin{array}{c}0.37 \\
5\end{array}$ & & $\begin{array}{c}0.19 \\
2\end{array}$ \\
\hline Obs. & 108 & 108 & 108 & 108 & 108 & 108 & 108 & 108 & 108 & 108 & 108 & 108 \\
\hline \multicolumn{13}{|c|}{ After Crisis $2010-2015$} \\
\hline \multirow[b]{2}{*}{$\begin{array}{l}\text { Vari } \\
\text { able } \\
\mathrm{s}\end{array}$} & \multicolumn{2}{|c|}{ MB } & \multicolumn{2}{|c|}{$\mathrm{PE}$} & \multicolumn{2}{|c|}{ ATO } & \multicolumn{2}{|c|}{ ROA } & \multicolumn{2}{|c|}{ ROE } & \multicolumn{2}{|c|}{ EPS } \\
\hline & $\begin{array}{l}\text { Mod } \\
\text { el1 }\end{array}$ & $\begin{array}{c}\text { Mod } \\
\text { el2 }\end{array}$ & $\begin{array}{l}\text { Mod } \\
\text { el1 }\end{array}$ & $\begin{array}{c}\text { Mo } \\
\text { del } \\
2 \\
\end{array}$ & $\begin{array}{l}\text { Mod } \\
\text { el1 }\end{array}$ & $\begin{array}{c}\text { Mo } \\
\text { del } \\
2 \\
\end{array}$ & $\begin{array}{c}\text { Mod } \\
\text { el1 }\end{array}$ & $\begin{array}{c}\text { Mo } \\
\text { del2 }\end{array}$ & $\begin{array}{c}\text { Mo } \\
\text { del } \\
1\end{array}$ & $\begin{array}{c}\text { Mod } \\
\text { el2 }\end{array}$ & $\begin{array}{c}\text { Mode } \\
11\end{array}$ & $\begin{array}{c}\text { Mod } \\
\text { el2 }\end{array}$ \\
\hline $\begin{array}{l}\text { Con } \\
\text { stant }\end{array}$ & $\begin{array}{c}- \\
0.86 \\
5^{*}\end{array}$ & $\begin{array}{c}- \\
1.94 \\
2\end{array}$ & 8.341 & $\begin{array}{l}4.6 \\
29\end{array}$ & $\begin{array}{l}2.35 \\
5^{* *}\end{array}$ & $\begin{array}{c}- \\
1.1 \\
53^{*}\end{array}$ & $\begin{array}{c}- \\
0.18 \\
0 * * *\end{array}$ & $\begin{array}{c}- \\
0.2 \\
76^{*} \\
*\end{array}$ & $\begin{array}{c}- \\
19 . \\
625\end{array}$ & $\begin{array}{c}- \\
25.4 \\
29\end{array}$ & 2.277 & $\begin{array}{c}- \\
2.22 \\
8\end{array}$ \\
\hline \multicolumn{13}{|c|}{ Control variables } \\
\hline $\begin{array}{c}\text { FAG } \\
\text { E }\end{array}$ & $\begin{array}{c}0.14 \\
0^{* *}\end{array}$ & $\begin{array}{l}0.12 \\
4 * * *\end{array}$ & 0.000 & $\begin{array}{c}- \\
0.0 \\
17\end{array}$ & $\begin{array}{c}0.01 \\
9\end{array}$ & $\begin{array}{c}- \\
0.0 \\
04\end{array}$ & $\begin{array}{c}0.00 \\
6\end{array}$ & $\begin{array}{c}- \\
0.0 \\
05\end{array}$ & $\begin{array}{c}- \\
0.0 \\
51\end{array}$ & $\begin{array}{c}- \\
0.05 \\
4\end{array}$ & 0.092 & $\begin{array}{c}0.09 \\
9\end{array}$ \\
\hline $\begin{array}{l}\text { FSI } \\
\text { ZE }\end{array}$ & $\begin{array}{c}0.08 \\
4\end{array}$ & $\begin{array}{c}0.13 \\
3\end{array}$ & $\begin{array}{c}- \\
0.011\end{array}$ & $\begin{array}{c}0.0 \\
06\end{array}$ & $\begin{array}{c}0.24 \\
2^{*}\end{array}$ & $\begin{array}{c}0.1 \\
28^{*}\end{array}$ & $\begin{array}{l}0.21 \\
7 * *\end{array}$ & $\begin{array}{c}0.2 \\
16^{*} \\
*\end{array}$ & $\begin{array}{c}0.2 \\
00^{*}\end{array}$ & $\begin{array}{c}0.14 \\
7\end{array}$ & $\begin{array}{c}0.157 \\
* * *\end{array}$ & $\begin{array}{c}0.16 \\
0 * * *\end{array}$ \\
\hline $\begin{array}{c}\text { FLE } \\
\mathrm{V}\end{array}$ & $\begin{array}{c}0.53 \\
7^{*}\end{array}$ & $\begin{array}{c}0.53 \\
6^{*}\end{array}$ & $\begin{array}{c}- \\
0.040\end{array}$ & $\begin{array}{c}- \\
0.0 \\
38 \\
\end{array}$ & $\begin{array}{c}0.02 \\
3 \\
\end{array}$ & $\begin{array}{c}- \\
0.0 \\
12 \\
\end{array}$ & $\begin{array}{c}- \\
0.14 \\
3 * * * \\
\end{array}$ & $\begin{array}{c}- \\
0.1 \\
23 \\
\end{array}$ & $\begin{array}{c}- \\
0.1 \\
09 \\
\end{array}$ & $\begin{array}{c}0.08 \\
0 \\
\end{array}$ & $\begin{array}{c}- \\
0.112\end{array}$ & $\begin{array}{c}- \\
0.11 \\
3 \\
\end{array}$ \\
\hline HCE & $\begin{array}{c}- \\
0.18 \\
8 * *\end{array}$ & & $\begin{array}{c}- \\
0.163\end{array}$ & & $\begin{array}{l}0.08 \\
6^{* *}\end{array}$ & & $\begin{array}{c}0.09 \\
1\end{array}$ & & $\begin{array}{l}0.0 \\
33\end{array}$ & & 0.053 & \\
\hline SCE & $\begin{array}{c}0.13 \\
2 \\
\end{array}$ & & 0.102 & & $\begin{array}{c}0.00 \\
7 \\
\end{array}$ & & $\begin{array}{c}0.26 \\
7 *\end{array}$ & & $\begin{array}{l}0.2 \\
44 * \\
\end{array}$ & & $\begin{array}{c}- \\
0.032 \\
\end{array}$ & \\
\hline CEE & $\begin{array}{c}- \\
0.04 \\
9\end{array}$ & & $\begin{array}{c}- \\
0.222 \\
*\end{array}$ & & $\begin{array}{c}- \\
0.93 \\
2^{*} \\
\end{array}$ & & $\begin{array}{c}0.05 \\
4\end{array}$ & & $\begin{array}{l}0.0 \\
43\end{array}$ & & 0.126 & \\
\hline $\begin{array}{c}\text { VAI } \\
\text { C }\end{array}$ & & $\begin{array}{c}0.09 \\
7\end{array}$ & & $\begin{array}{l}0.1 \\
26\end{array}$ & & $\begin{array}{c}- \\
0.0 \\
05\end{array}$ & & $\begin{array}{c}0.0 \\
51\end{array}$ & & $\begin{array}{l}0.16 \\
8 * * *\end{array}$ & & $\begin{array}{c}0.02 \\
9\end{array}$ \\
\hline
\end{tabular}




\begin{tabular}{|c|c|c|c|c|c|c|c|c|c|c|c|c|}
\hline $\begin{array}{c}\text { F- } \\
\text { Stat. }\end{array}$ & $\begin{array}{c}16.6 \\
3 \\
\end{array}$ & $\begin{array}{c}10.1 \\
8\end{array}$ & 3.35 & $\begin{array}{c}3.3 \\
3 \\
\end{array}$ & 2.28 & $\begin{array}{r}230 \\
.20 \\
\end{array}$ & 2.98 & $\begin{array}{c}3.3 \\
3 \\
\end{array}$ & $\begin{array}{c}2.5 \\
1 \\
\end{array}$ & 3.39 & 3.24 & 2.21 \\
\hline $\begin{array}{l}\text { Prob } \\
\text { (F) }\end{array}$ & $\begin{array}{c}0.00 \\
0 \\
\end{array}$ & $\begin{array}{c}0.00 \\
0 \\
\end{array}$ & 0.012 & $\begin{array}{l}0.0 \\
02 \\
\end{array}$ & $\begin{array}{c}0.06 \\
2 \\
\end{array}$ & $\begin{array}{l}0.0 \\
00 \\
\end{array}$ & $\begin{array}{c}0.02 \\
1 \\
\end{array}$ & $\begin{array}{l}0.0 \\
02\end{array}$ & $\begin{array}{l}0.0 \\
44 \\
\end{array}$ & $\begin{array}{c}0.00 \\
2 \\
\end{array}$ & 0.014 & $\begin{array}{c}0.03 \\
6 \\
\end{array}$ \\
\hline $\begin{array}{l}\text { R- } \\
\text { squa } \\
\text { re }\end{array}$ & $\begin{array}{c}0.29 \\
8\end{array}$ & $\begin{array}{c}0.31 \\
7\end{array}$ & 0.079 & $\begin{array}{l}0.1 \\
32\end{array}$ & $\begin{array}{c}0.05 \\
5\end{array}$ & $\begin{array}{c}0.9 \\
13\end{array}$ & $\begin{array}{c}0.07 \\
1\end{array}$ & $\begin{array}{l}0.1 \\
32\end{array}$ & $\begin{array}{l}0.0 \\
60\end{array}$ & $\begin{array}{c}0.13 \\
4\end{array}$ & 0.076 & $\begin{array}{c}0.09 \\
2\end{array}$ \\
\hline $\begin{array}{l}\text { R- } \\
\text { Squa } \\
\text { re } \\
\text { Cha } \\
\text { nge }\end{array}$ & & $\begin{array}{c}0.01 \\
9\end{array}$ & & $\begin{array}{c}0.0 \\
53\end{array}$ & & $\begin{array}{c}0.8 \\
58\end{array}$ & & $\begin{array}{l}0.0 \\
61\end{array}$ & & $\begin{array}{c}0.07 \\
3\end{array}$ & & $\begin{array}{c}0.01 \\
5\end{array}$ \\
\hline Obs. & 162 & 162 & 162 & 162 & 162 & 162 & 162 & 162 & 162 & 162 & 162 & 162 \\
\hline
\end{tabular}

Hints: coefficients of regression reported as standardized coefficients. *. Correlation is significant at the 0.01 level, ** Correlation is significant at the 0.05 level and ***

Correlation is significant at the 0.10 level. VIF value for all control and independents variables are less than 3 , means there is no Multicollinearity.

\section{Conclusion}

Intellectual capital has become the main resource of value creation. it is especially true in knowledge-based economy, such as real estate sector, where the value added of companies and individuals has direct association with their knowledge and intellectual capital (Bontis, 2001). The main purpose of this study is to investigate the relationship of intellectual capital and its components (human capital, structural capital, and capital employed) on market, productivity, and financial performance of real estate companies listed on Borsa Istanbul before and after the crisis. The paper is conducted by using the data from 27 company's annual reports listed on Borsa Istanbul. Pulic's method VAIC was used as a measurement of intellectual capital, where MB and PE ratios used as indicators of market performance, ATO ratio is used as indicator of productivity performance, and ROA, ROE and EPS ratios used as indicators of financial performance. The findings show that SCE is the most effective factor in the issue of value creation than HCE and CEE for the study period before and after the crisis especially with financial measures indicators ROA, ROE, and EPS. HCE plays a considerable role in value creation before the crisis where has a significant impact on financial performance indicators ROA and ROE. CEE does not consider as an engine to value creation before and after the crisis. This means that the Turkish companies depend on intellectual assets rather than physical assets before and after the crisis. Although, VAIC shows a good association with financial performance of the real estate companies before and after the crisis. In general, one can say that real estate Turkish companies still weakly used its intellectual capital to create value.

The findings of the study are consistent with the previous studies e.g. Narwal \& Yadav, (2017); Bontis et al., (2000); Muhammad \& Ismail, (2014); 
Goh (2005); El-Bannany, (2012); Shih et al., (2010); Mondal \& Ghosh, (2012); Mention \& Bontis, (2013); Joshi et al., (2010); Yalama \& Coskun, (2007). And partly consistent with the previous studies e.g. Holienka \& Pilková, (2014); Sumedrea, (2013) and Radianto, (2011). While fully inconsistent with Pitelli Britto et al., (2014).

The limitations of this study are represented in the lack of data sources where there are some companies were omited because of the missing values during the study's period. Therefore, the findings of the study cannot generalize for other sectors because of the differences in the nature of those sectors.

\section{References:}

1. Abdulsalam, F., Al-Qaheri, H., \& Al-Khayyat, R. (2011). The Intellectual Capital Performance of KuwaitiBanks: An Application of vaicTM1 Model. iBusiness, 03(01), 88-96.

2. Al-Zoubi, M. R. (2013). The Impact of Intellectual Capital on SWOT Analysis among Jordanian Banking Industry“Empirical Study." International Journal of Business and Social Science, 4(2).

3. Basso, L. F. C., Kimura, H., \& da Aguiar, J. F. (2010). Intellectual capital and value creation in the production and assembly of vehicles and auto-parts sector in Brazil: a panel data analysis. Journal of Modern Accounting and Auditing, 6(8), 15.

4. Bontis, N. (1998). Intellectual capital: an exploratory study that develops measures and models. Management Decision, 36(2), 63-76.

5. Bontis, N. (2001). Assessing knowledge assets: a review of the models used to measure intellectual capital. International Journal of Management Reviews, 3(1), 41-60.

6. Bontis, N., Chua Chong Keow, W., \& Richardson, S. (2000). Intellectual capital and business performance in Malaysian industries. Journal of Intellectual Capital, 1(1), 85-100.

7. Bozbura, F. T. (2004). Measurement and application of intellectual capital in Turkey. The Learning Organization, 11(4/5), 357-367.

8. Brooking, A. (1996). Intellectual Capital: Core Assets for the Third Millennium Enterprise. London, UK: Thomson Business Press.

9. Cabrita, M. D. R., \& Bontis, N. (2008). Intellectual capital and business performance in the Portuguese banking industry. International Journal of Technology Management, 43(1-3), 212-237.

10. Cabrita, M. D. R., \& Vaz, J. L. (2005). Intellectual Capital and Value Creation: Evidence from the Por-tuguese Banking Industry. Electronic Journal of Knowledge Management, 4(1), 11-20.

11. Calisir, F., Altin Gumussoy, C., Cirit, F., Yorulmaz, E., \& Bayraktaroglu, A. E. (2010). Intellectual Capital in Turkish Private 
Banks (pp. 189-194). SciTePress - Science and and Technology Publications.

12. Calisir, F., Gumussoy, C. A., Cirit, F., \& Bayraktaroglu, A. E. (2011). Intellectual capital in development and investment banks of Turkey. In International Conference on Industrial Engineering and Operations Management, Kuala Lumpur (pp. 22-24).

13. Chang, W. S. (2010). The Different Proportion of IC Components and Firms' Market Performance: Evidence from Taiwan. The International Journal of Business and Finance Research, 4(4), 121-134.

14. Goh, P. (2005). Intellectual capital performance of commercial banks in Malaysia. Journal of Intellectual Capital, 6(3), 385-396.

15. Chen, M., Cheng, S., \& Hwang, Y. (2005). An empirical investigation of the relationship between intellectual capital and firms' market value and financial performance. Journal of Intellectual Capital, 6(2), 159176.

16. Edvinsson, L. (1997). Developing intellectual capital at Skandia. Long Range Planning, 30(3), 366-373.

17. Edvinsson, L., \& Malone, M. S. (1997). Intellectual Capital: Realizing Your Company's True Value by Finding Its Hidden Brainpower (1st edition). New York: HarperBusiness.

18. El-Bannany, M. (2008). A study of determinants of intellectual capital performance in banks: the UK case. Journal of Intellectual Capital, 9(3), 487-498.

19. El-Bannany, M. (2012). Global financial crisis and the intellectual capital performance of UAE banks. Journal of Human Resource Costing \& Accounting, 16(1), 20-36.

20. Holienka, M., \& Pilková, A. (2014). Impact of Intellectual Capital and its Components on Firm Performance before and After Crisis. Electronic Journal of Knowledge Management, 12(4).

21. Huihui, Z., \& Jitian, W. (2010). Study on the Relationship between Intellectual Capital and Financial Performance of Real Estate Companies (pp. 72-75).

22. Joshi, M., Cahill, D., \& Sidhu, J. (2010). Intellectual capital performance in the banking sector: An assessment of Australian owned banks. Journal of Human Resource Costing \& Accounting, 14(2), 151170.

23. Jurczak, J. (2008). Intellectual Capital Measurement Methods. Economics and Organization of Enterprise, 1(1), 37-45.

24. Kamath, G. B. (2007). The intellectual capital performance of the Indian banking sector. Journal of Intellectual Capital, 8(1), 96-123.

25. Khalique, M., Shaari, N., Abdul, J., \& Isa, A. H. B. M. (2011). Intellectual capital and its major components. 
26. Kujansivu, P., \& Lönnqvist, A. (2007). Investigating the value and efficiency of intellectual capital. Journal of Intellectual Capital, 8(2), 272-287.

27. Lev, B. (2001). Intangibles: Management, Measurement and Reporting. Brookings Institution Press.

28. Luthy, D. H. (1998). Intellectual capital and its measurement. In Proceedings of the Asian Pacific Interdisciplinary Research in Accounting Conference (APIRA), Osaka, Japan (pp. 16-17).

29. Mårtensson, M. (2000). A critical review of knowledge management as a management tool. Journal of Knowledge Management, 4(3), 204216.

30. Mavridis, D. G. (2004). The intellectual capital performance of the Japanese banking sector. Journal of Intellectual Capital, 5(1), 92-115.

31. Mavridis, D. G., \& Kyrmizoglou, P. (2005). Intellectual capital performance drivers in the Greek banking sector. Management Research News, 28(5), 43-62.

32. Mayo, A. (2001). Human Value of the Enterprise. Nicholas Brealey Publishing London.

33. Meihami, B., Varmaghani, Z., \& Meihami, H. (2013). Role of Intellectual Capital on Firm Performance (Evidence from Iranian Companies). International Letters of Social and Humanistic Sciences, $12,43-50$.

34. Mention, A., \& Bontis, N. (2013). Intellectual capital and performance within the banking sector of Luxembourg and Belgium. Journal of Intellectual Capital, 14(2), 286-309.

35. Mondal, A., \& Ghosh, S. K. (2012). Intellectual capital and financial performance of Indian banks. Journal of Intellectual Capital, 13(4), $515-530$.

36. Moradi, M., Saeedi, M., Hajizadeh, H., \& Mohammadi, M. (2013). The Influence of Intellectual Capital on the Improvement of Companies' Financial Performance. International Journal of Economics, Business and Finance, 1(5), 120-139.

37. Mosavi, S. A., Nekoueizadeh, S., \& Ghaedi, M. (2012). A study of relations between intellectual capital components, market value and finance performance. African Journal of Business Management, 6(4).

38. Muhammad, N. M. N., \& Ismail, M. K. A. (2009). Intellectual capital efficiency and firm's performance: study on Malaysian financial sectors. International Journal of Economics and Finance, 1(2), 206.

39. Muhammad, N. M. N., \& Ismail, M. K. A. (2014). Intellectual capital efficiency and firm's performance: Study on Malaysian Financial Sectors. International Journal of Economics and Finance, 1(2), p206. 
40. Narwal, K. P., \& Yadav, N. (2017). The Impact of Intellectual Capital on the Indian Real Estate Sector Profitability and Productivity. Journal of Commerce and Accounting Research, 6(1).

41. Ozkan, N., Cakan, S., \& Kayacan, M. (2016). Intellectual Capital and Financial Performance: A Study of the Turkish Banking Sector. Borsa Istanbul Review.

42. Peppard, J., \& Rylander, A. (2001). Using an intellectual capital perspective to design and implement a growth strategy: the case of APiON. European Management Journal, 19(5), 510-525.

43. Pitelli Britto, D., Monetti, E., \& da Rocha Lima Jr, J. (2014). Intellectual capital in tangible intensive firms: the case of Brazilian real estate companies. Journal of Intellectual Capital, 15(2), 333-348.

44. Pulic, A. (1998). Measuring the performance of intellectual potential in knowledge economy. In 2nd McMaster Word Congress on Measuring and Managing Intellectual Capital by the Austrian Team for Intellectual Potential.

45. Pulic, A. (2000). VAICTM-an accounting tool for IC management. International Journal of Technology Management, 20(5-8), 702-714.

46. Pulic, A. (2004). Intellectual capital - does it create or destroy value? Measuring Business Excellence, 8(1), 62-68.

47. Pulic, A. (2008). The principles of intellectual capital efficiency-A brief description. Croatian Intellectual Capital Center, Zagreb, 76.

48. Radianto, W. E. (2011). The influence of intellectual capital on banking industry performance: a case in indonesia stock exchange before and after the 2008 global financial crisis. Asia Pacific Journal of Accounting and Finance, 2, 1.

49. Rehman, M. U., Ahmed, K., \& Qazi, A. Q. (2014). A study of causality between disintegrated intellectual capital and firm performance.

50. Rehman, W. U., Rehman, H. U., Usman, M., \& Asghar, N. (2012). A Link of intellectual capital performance with corporate performance: comparative study from banking sector in Pakistan. International Journal of Business and Social Science, 3(12).

51. Roos, G., \& Roos, J. (1997). Measuring your company's intellectual performance. International Journal of Strategic Management, Long Range Planning, 30(3), 413-426.

52. Roos, G., Roos, J., Dragonetti, N. C., \& Edvinsson, L. (1997). Intellectual Capital: Navigating in the New Business Landscape. London, UK: Macmillan Publications.

53. Shih, K., Chang, C., \& Lin, B. (2010). Assessing knowledge creation and intellectual capital in banking industry. Journal of Intellectual Capital, 11(1), 74-89. 
54. Stewart, T. (1997). Intellectual Capital: The New Wealth of Organizations (illustrated, reprint). Business Digest, New York: Doubleday / Currency.

55. Stewart, T. (2002). The Wealth of Knowledge: Intellectual Capital and the Twenty-First Century Organization. London: Nicholas Brealey Publishing Limited.

56. Sullivan, P. H. (1999). Profiting from intellectual capital. Journal of Knowledge Management, 3(2), 132-143.

57. Sumedrea, S. (2013). Intellectual Capital and Firm Performance: A Dynamic Relationship in Crisis Time. Procedia Economics and Finance, 6, 137-144.

58. Sveiby, K. E. (1997). The new organizational wealth: managing \& measuring knowledge-based assets (1st ed). San Francisco: BerrettKoehler Publishers.

59. Sydler, R., Haefliger, S., \& Pruksa, R. (2014). Measuring intellectual capital with financial figures: Can we predict firm profitability? European Management Journal, 32(2), 244-259.

60. Tayles, M., Pike, R. H., \& Sofian, S. (2007). Intellectual capital, management accounting practices and corporate performance: Perceptions of managers. Accounting, Auditing \& Accountability Journal, 20(4), 522-548.

61. Yalama, A., \& Coskun, M. (2007). Intellectual capital performance of quoted banks on the Istanbul stock exchange market. Journal of Intellectual Capital, 8(2), 256-271.

62. Zeghal, D., \& Maaloul, A. (2010). Analysing value added as an indicator of intellectual capital and its consequences on company performance. Journal of Intellectual Capital, 11(1), 39-60.

63. Alessandri, T., Cerrato, D., Depperu, D. (2014). Organizational slack, experience and acquisition behavior across varying economic environments. Management Decision, vol. 56, no. 5, p. 967-982. 